\title{
Apoptosis and Senescence - Main Mechanisms of Accelerated Aging of Haematopoietic Cells after Irradiation
}

\author{
Jiřina Vávrová1, Martina Řezáčová ${ }^{2}$ \\ ${ }^{1}$ Department of Radiobiology, Faculty of Military Health Sciences, University of Defence, Hradec Králové, \\ Czech Republic \\ ${ }^{2}$ Department of Medical Biochemistry, Faculty of Medicine in Hradec Králové, Charles University in Prague, \\ Czech Republic
}

Received August 11, 2008

Accepted December 15, 2008

\begin{abstract}
Haematopoietic stem cell (HSC) is one of the most radiosensitive cells in organism. In mice it is characterized as $\operatorname{lin}^{-} \mathrm{Sca}-1^{+} \mathrm{CD} 117^{+}$cell. This review discusses the role of HSC subpopulations in recovery of haematopoiesis after irradiation, and molecular mechanisms of reaction of HSC to damage induced by genotoxic stress, mainly to double strand breaks (DSB) of DNA. Various proteins are accumulated on the site of break, e.g. 53BP1 and $\gamma \mathrm{H} 2 \mathrm{AX}$. Repair of the damage and related signalling is executed by many proteins, such as ATM, ATR, and DNA-PK kinases, MRN complex and proteins of homologous recombination and non-homologous end joining. Repetitive irradiation by low doses of ionizing radiation causes in HSC accumulation of proteins into so-called "ionizing radiation inducing foci" (detectable by $\gamma \mathrm{H} 2 \mathrm{AX}$ ) and decreases repair capacity of HCS. Furthermore, two possible molecular mechanisms of HSC reaction to radiationinduced DNA damage are discussed - apoptosis and senescence. While majority of differentiated haematopoietic cells, leukaemic cells, and haematopoietic progenitors die after irradiation by apoptosis, in HSC also senescence was detected. It also seems that decrease in proliferative capacity of HSC related to old age is caused by accumulation of DNA damage induced by oxygen radicals in the pool of quiescent stem cells.
\end{abstract}

Review, haematopoietic stem cell, radiation, apoptosis, senescence

Damage of cells by ionizing radiation includes mainly modifications of DNA molecules, such as single and double-strand breaks (DSB). While single-strand breaks are quickly repaired in a process that requires poly-(ADP-ribose)-polymerase (PARP), DSB represent potentially lethal damage and their repair is complicated. Imperfect DNA repair causes mutations and contributes to genome instability. This is mostly manifested as chromosome aberrations, interchromosomal and intrachromosomal rearrangements (dicentric aberrations, translocations, or inversions). Detection of chromosomal aberrations in peripheral lymphocytes is an important indicator of obtained dose of radiation (Kozubek 2000).

Haematopoietic stem cells (HSC) function throughout life to generate all of the effector's cells of the haematopoietic system. HSC are imbued with enormous developmental potential; even a single stem cell can reconstitute the entire blood system (Gazit et al. 2008). The degree of damage to haematopoiesis is a critical factor influencing mortality of mice irradiated by doses lower than 10 Gy. Already in 1961 a method for evaluation of dose-dependent effect of ionizing radiation on haematopoietic progenitor cells of mice was described by Till and McCulloch. They applied bone marrow, irradiated by increasing dose of radiation, to lethally irradiated recipient and detected number of exogenous haematopoietic colonies in spleen (CFU-S). The generated dose-response curves described dependency of number of CFU-S on the received dose of ionizing radiation. $\mathrm{D}_{0}$ dose (value which determines dose of radiation that $37 \%$ of cells survive) was around $1 \mathrm{~Gy}$ (McCulloch and Till 1962). In our recent studies $\mathrm{D}_{0}$ values were confirmed also for human stem cells isolated from peripheral blood of healthy donors after mobilization with

Address for correspondence:

Prof. RNDr. Jiřina Vávrová, CSc.

Department of Radiobiology

University of Defence, Faculty of Military Health Sciences

Trebešská 1575, 50001 Hradec Králové, Czech Republic
Phone: $+420973253214,+420776050946$

Fax: +420 495513018

E-mail: vavrova@pmfhk.cz

http://www.vfu.cz/acta-vet/actavet.htm 
granulocyte-colony stimulating factor (G-CSF). The stem cells were isolated by COBE Spectra separator and then $\mathrm{CD} 133^{+}$cells were isolated using immunomagnetic selection. $\mathrm{D}_{0}$ value determined for erythroid progenitors (BFU-E) is 0.95 Gy and for myeloid progenitor (CFU-GM) 1.08 Gy (Vávrová et al. 2002).

With low radiation doses (below 1 Gy) one can see a shoulder on the dose response curve; it means that more cells in reality survive low radiation doses than would correspond to linear dependence. Such dependence can be mathematically characterized by linear quadratic equation: surviving fraction (SF) is generally expressed as $S F=e^{-\left(\alpha D+\beta D^{2}\right)}$, where $D$ is the dose in Gy. Parameters $\alpha$ and $\beta$ are different for different tissues, cell types, and types of radiation. For bone marrow the $\alpha / \beta$ ratio is high (Denekamp 1986), which reflects dominance of linear component $(\alpha)$. Therefore fractionation of the dose has relatively low importance in repair of radiation-induced damage of haematopoiesis. The effects of different dose rates of in vitro irradiation on the proliferative capacity of marrow stromal, haematopoietic and leukaemia colony-forming cells was studied in 1987 by Laver et al. Marrow cell suspensions, leukaemic HL-60 cells and trypsin dispersed fibroblasts were irradiated at 0.05 or $0.45 \mathrm{~Gy} / \mathrm{min}$ and then assayed for colony formation. Irradiation at low $(0.05 \mathrm{~Gy} / \mathrm{min})$ compared to high $(0.45 \mathrm{~Gy} / \mathrm{min})$ dose rate showed a significant difference in survival of stromal and HL-60 cells, but not of haematopoietic progenitors: $\mathrm{D}_{0}$ value were 1.7 and 1.4 Gy for marrow fibroblast progenitors (CFU-F), 1.7 and 1.4 Gy for HL-60, but 1.25 and 1.2 Gy for BFU-E and 1.15 and 1.2 Gy for CFU-GM. Also p53 status seems to play important role in response to low dose rate irradiation. It can be concluded from our own results (Vávrová et al. 2004) that for the determination of dose-rate to be used in the treatment strategy, two main points should be considered $-\mathrm{i}$ ) the type of cells (mainly their p53 status) and ii) G2 phase arrest length i.e. the time which the cells have for damage repair. While the effect of radiation of human T-lymphocyte leukaemia cells MOLT-4 (p53 wild type) is not significantly affected by the dose-rate, the dose rate has significant effect on HL-60 cells. The presence of cells in G2 phase during irradiation increases radioresistance of these cells.

It also seems that irradiation by high doses (5 Gy) induces deep decrease in CFU-S 14 days after irradiation with haematopoiesis recovery 21 days after irradiation (Vávrová and Petýrek 1986, 1988). Their studies of single whole body irradiation of mice by the dose of 5 Gy detected deep decrease in ability of marrow cells to form exogenous CFU-S during first 14 days after irradiation. On day 21 haematopoiesis recovery and ability to form exogenous CFU-S was seen, but the recovery is not permanent and 180 days after the irradiation secondary decrease manifested. This decrease in ability to form CFU-S further deepened till day 360 after irradiation. With repetitive irradiation $(4 \times 5$ Gy) during 21 days the secondary decrease in exogenous CFU-S formation 180 or 360 days after the irradiation was significantly stronger. It can be concluded that short-term increase of CFU-S number depends on recovery of number of progenitor cells, but from a long-term view the regeneration of HSC is insufficient, either due to increased cell death or induction of senescence, and results in decrease in progenitor cells number manifested as decrease in CFU-S formation.

\section{Murine haematopoietic stem cells}

All activities of haematopoietic stem cells in mice are related with lineage- (lin'), Sca- $1^{+}$and $\mathrm{CD}_{117^{+}}$(ckit $^{+}$) cells (Yang et al. 2005). Randall et al. (1996) showed that a population of adult bone marrow that is characterized as $\operatorname{lin}^{-} \mathrm{CD} 117^{+} \mathrm{Sca}-1^{+}$contained most of the day-12 colony-forming units-spleen. However, this population contains at least two subpopulations with different function: the first subpopulation consists of cells with high self-renewal capacity (long-term repopulating HSC - LT-HSC), and the 
second subpopulation consists of cells more committed to particular lineage - short-term repopulating HSC (ST-HSC).

Mouse has very few LT-HSC in bone marrow (1-2 cells per 100000 cells in bone marrow). It was determined that the functional population of LT-HSC corresponds with phenotype lin-Sca- $1^{+} \mathrm{CD} 117^{+} \mathbf{C D 3 8}^{+} \mathbf{C D 3 4}^{-}$and such cells can be isolated using five-colour flowcytometry and sorting (Zhao et al. 2000). However, these cells when transplanted alone into lethally irradiated recipient are not able to reconstitute functions of haematopoietic system quickly enough to prevent death. After transplantation of $\operatorname{lin}^{-} \mathrm{Sca}-1^{+} \mathrm{CD} 117^{+} \mathbf{C D}^{+} \mathbf{C D}^{+} \mathbf{C D}^{-}$ together with lin-Sca- $1^{+} \mathrm{CD} 117^{+} \mathbf{C D 3 8}^{-\mathbf{C D}^{-} 4^{+}}$(ST-HSC), haematopoiesis is restored quickly and sufficiently for long-term survival. Not only are LT-HSC rare in bone marrow, but it was also found that only $20 \%$ of them are involved in long-term reconstitution of haematopoiesis (Morrison at al 1995; Wagers et al. 2002), suggesting that subpopulations of LT-HSC with different functions may also exist. During maturation of cells CD38 antigen seems to be lost in the same time when CD34 begins to be expressed, as majority of CD $38^{+}$cells is also CD34-, and majority of CD38- cells is CD34+ (Zhao et al. 2000).

More abundant HSC in mouse are ST-HCS. These cell phenotypes were described by Yang et al. (2005), who studied $\operatorname{lin}^{-} \mathrm{Sca}^{+} \mathrm{CD} 117^{+}$cells and found that vast majority of them is $\mathrm{CD} 4^{+}$. These lin-Sca- $1^{+} \mathrm{CD} 117^{+} \mathrm{CD} 34^{+}$cells have the ability to form CFU-S and are responsible for quick reconstitution of haematopoiesis when transplanted to lethally irradiated recipient, but cannot replenish undifferentiated LT-HSC with high self-renewal capacity. Population of ST-HCS can be further classified into two subgroups according to expression of Flt3. ST-HSC lin-Sca- $1^{+} \mathrm{CD} 117^{+} \mathrm{CD} 34^{+}$flt 3 - fully meet criteria of ST-HCS, are responsible for exogenous CFU-S formation, and reconstitution of myelopoiesis. ST-HSC which express Flt3 (lin-Sca- $1^{+} \mathrm{CD} 117^{+} \mathrm{CD} 34^{+} \mathbf{f l t} 3^{+}$) are responsible for reconstitution of lymphopoiesis (Yang et al. 2005). The development of surface markers during maturation of haematopoietic precursors is summarized in Fig. 1.

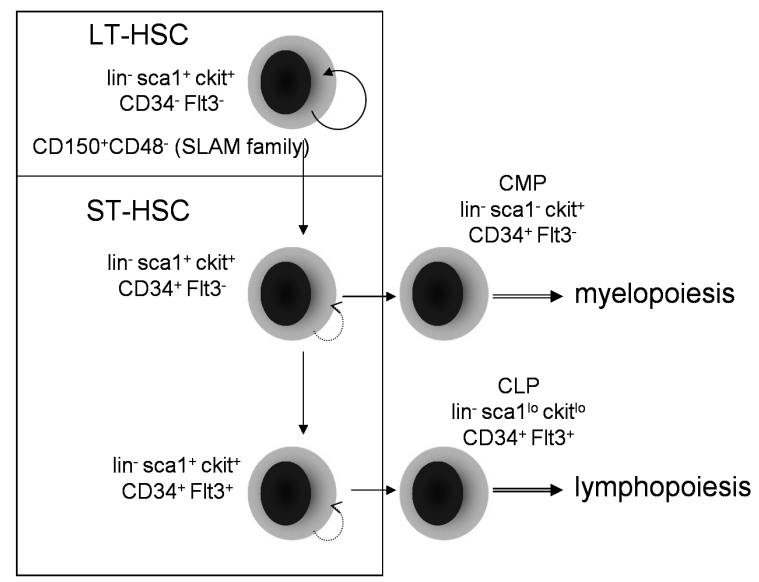

Fig. 1. Differentiation of murine haematopoietic stem cells

So far it is necessary to use complex combinations of markers for reliable purification of HSC. Therefore simple markers which could reliably identify HSC in various phases of development are intensively researched. Kiel et al. (2005) found that SLAM family receptors are differentially expressed among haematopoietic progenitors in a way that correlates with progenitor primitiveness. They describe an alternative method for HSC 
identification using cell surface receptors of the SLAM family, including CD150, CD244 and CD48. HSC were highly purified as CD150 ${ }^{+} \mathrm{CD} 244{ }^{-C D} 48^{-}$cells, while multipotent haematopoietic progenitors were $\mathrm{CD} 150^{-} \mathrm{CD} 244^{+} \mathrm{CD} 48^{-}$, and most restricted progenitors were $\mathrm{CD} 150^{-} \mathrm{CD} 244^{+} \mathrm{CD} 48^{+}$. Yilmaz et al. (2006) detected equal expression of SLAM family receptors on HSC isolated from young, old, and reconstituted mice bone marrow. They also proved that $\operatorname{lin}-\mathrm{Sca}-1^{+} \mathrm{CD} 117^{+}$selection combined with $\mathrm{CD} 150^{+} \mathrm{CD} 48^{-}$selection isolates population much more highly enriched for HSCs, with dramatically increased ability to reconstitute haematopoiesis. One in 3 to 1 in 7 cells gave a long-term multilineage reconstitution in lethally irradiated recipients. However, their findings are in contrast with recent observations of Weks berg et al. (2008). They prove that both CD150+ and CD150cells can provide long-term reconstitution of haematopoiesis.

Probably the most interesting feature of stem cells - besides the ability to self-renew - is the ability to produce a broad spectrum of cell types. Every tissue-specific stem cell is universal insofar that it can produce many different cell types, which constitute the actual tissue. However, stem cell abilities are not limited to the production of tissuespecific progeny. Stem cells also exhibit plasticity, when the stem cells derived from a particular tissue can be reprogrammed by influence of a specific microenvironment of other tissue for production of different elements (e.g. neural stem cells can reconstitute haematopoiesis (Filip et al. 2004), or bone marrow stem cells can reconstitute skeletal muscle (Yoshimoto et al. 2005; Abedi et al. 2004). Such specific microenvironment is called niche. The importance of niche can also be demonstrated in tissue damage caused by chronic irritation. Chronic irritation causes changes in the niche, affecting SC and tissue homeostasis, and can start tumorigenesis.

Decreased ability of stem cells to maintain a tissue homeostasis is the main physiological characteristic of aging. The competitive transplantation studies using purified stem cells have shown that per-cell activity of HSC from old mice was substantially reduced compared to HSC from young mice. Various studies, using comparable methods, suggested that number of HSC increase with age by a factor 6 to 17 fold (Gazit et al. 2008; Rossi et al. 2005). It seems that one of the key factors, which are responsible for decrease in repopulating activity of stem cells during aging, is accumulation of DNA damage (Rossi et al. 2007). Majority of LT-HSC are cells in a "steady state", and serve only as a back-up population for reconstitution of the haematopoietic system, when it is damaged by stress conditions. In a live organism (such as mouse) acute myelosuppression is a result of severe ST-HCS damage and loss, and can be caused by various stressors, such as e.g. ionizing radiation. After such insult LT-HCS initiate self-renewal processes, proliferate, and differentiate into particular ST-HSC to restore homeostasis. If the self-renewal process itself is impaired by a long-term damage, the restoration of function of bone marrow is insufficient. Fortunately LT-HSC seems to have lower metabolic activity and in theirs quiescent state are less vulnerable to genotoxic stress.

\section{Apoptosis induction after irradiation}

During the studies of response of haematopoietic cells (HSC, lymphocytes and immortalized leukaemia cell lines) to ionizing radiation-induced damage it was proved that majority of haematopoietic cells die after irradiation by triggering apoptosis (Meng et al. 2003; Aldridge and Radford 1998; Vávrová et al. 2001; Vilasová et al. 2008). In vitro and in vivo irradiated lymphocytes isolated from peripheral blood (both quiescent in $\mathrm{G}_{0}$ phase and stimulated by phytohaemagglutinin - PHA) die after irradiation by programmed cell death - apoptosis (Hertveldt et al. 1997; Louagie et al.1998; Vokurková et al. 2006; Vilasová et al. 2008). This process is time-, and dose-dependent. It was demonstrated that in peripheral blood mononuclear cells isolated from blood of healthy donors and irradiated by the dose of 7 Gy apoptosis is not detectable within the first $6 \mathrm{~h}$, but $16 \mathrm{~h}$ after irradiation 
$50 \%$ of the cells are Annexin V-positive and $48 \mathrm{~h}$ after irradiation all cells are Annexin V-positive (Vokurková et al. 2006). The study of Vilasová et al. (2008) compares apoptosis induction in quiescent $\mathrm{CD}^{+}$and PHA-stimulated $\mathrm{T}$ lymphocytes. In both nonstimulated and PHA-stimulated lymphocytes $65-70 \%$ of cells were apoptotic $72 \mathrm{~h}$ after irradiation by the dose 4 Gy.

Apoptosis has been also suggested to be a major cause of cell death from continuous low-dose rate radiation from radioimmunotherapy (Kroger et al. 2001; Ning and Knox 1999). As we mentioned before, p53 status is important in response of tumor cells to low dose rate irradiation. This fact is probably related to differences in cell cycle checkpoint regulation. For example, the effect of irradiation on leukaemic MOLT-4 cells (p53 wild) is not significantly affected by dose-rate. X-irradiated MOLT-4 cells suffer from an interphase death as well as a reproductive death, and apoptosis is a mechanism responsible for both modes of the death in these cells. Irradiation with dose 3 Gy delivered by high dose rate causes only inexpressive accumulation of these cells in $S$ and $\mathrm{G}_{2}$ phases of cell cycle at $8 \mathrm{~h}$ after irradiation and maximum apoptosis is detected 12-16 h after irradiation (Szkand erová et al. 2003). In cancer cells the gene encoding p53 is often mutated or missing, and cell that lack functional p53 protein are arrested preferentially in the $\mathrm{G}_{2}$ phase of the cell cycle in response to DNA damage. For example, it was found (Vávrová et al. 2004) that the human promyelocyte leukaemia cells HL-60 (p53 negative) exposed to a ionizing radiation in the doses up to $10 \mathrm{~Gy}$ are arrested in the $\mathrm{G}_{2}$ phase for the period of $24 \mathrm{~h}$. When the HL-60 cells have been exposed to a low dose-rate $3.9 \mathrm{mGy} / \mathrm{min}$ (LDR) gamma irradiation, which resulted in a pronounced accumulation of the cells in the $\mathrm{G}_{2}$ phase during the exposure period, their radioresistance has increased in comparison with the cells irradiated with a high dose-rate $0.6 \mathrm{~Gy} / \mathrm{min}$ (HDR). The $\mathrm{D}_{0}$ value for LDR is $3.7 \mathrm{~Gy}$ and for HDR it is 2.2 Gy. The abrogation of the $\mathrm{G}_{2}$ phase arrest by caffeine $(2 \mathrm{mM})$ and irradiation of the cells with LDR in all phases of the cell cycle caused significant radiosensitisation $\left(D_{0}=2.1 \mathrm{~Gy}\right)$. The irradiation in the presence of caffeine has resulted in a second wave of apoptosis on 5 to 7 days after the irradiation exposure. Caffeine-induced apoptosis in later interval after the irradiation is probably a result of an unscheduled DNA replication and a cell cycle progress (Vávrová et al. 2003). Checkpoint machinery and cell cycle arrest are therefore extremely important in prolonged low-dose rate irradiation.

Mechanisms of effect of ionizing radiation on mouse HSC was studied by Meng et al. (2003). The dose of 4 Gy caused 95\% inhibition of cobblestone area-forming cells frequency. This dose also induced apoptosis in $65 \%$ of $\mathrm{Lin}-\mathrm{Sca}-1^{+} \mathrm{CD} 117^{+}$cells and in $50 \%$ of Lin $^{-S c a}-1^{-C D} 117^{+}$cells. The dose of $6.5 \mathrm{~Gy}$ (sublethal whole body irradiation) reduced significantly the number of HSC during the whole experiment, i.e. during 60 days after irradiation. However, also increase in $\mathrm{p} 16^{\text {Ink4a }}$ was detected on Lin-Sca- $1^{+} \mathrm{CD} 117^{+} \mathrm{HSC}$, which may indicate induction of senescence in these cells. Apoptosis induction by ionizing radiation in dose of 2.5 Gy was also proved in human $\mathrm{CD}_{133^{+}}$HSC. Although these cells were able to repair radiation-induced damage and entered cell cycle again after 7 days post-irradiation, their expansion ability was significantly reduced (Vávrová et al. 2002).

However, these mechanisms do not remove all damaged cells. Especially after low doses of radiation (0.2-0.3 Gy) the cells with some type of chromosomal aberrations (e.g. reciprocal translocations) persist. These cells are dangerous for organism, and due to their genomic instability they can be responsible for tumorigenesis. The prediction of the induction of malignant tumors by radiation in the range of low doses is normally assessed by the extrapolation of observed risk coefficients from relatively high doses ( $>1 \mathrm{~Gy})$ to low doses. Nevertheless, the low-dose data available from epidemiologic studies suggest that the risks per unit of dose at low doses and low dose rates are compatible with or even less than risks per unit of dose at higher doses (Shore 1999). It seems that DNA repair 
machinery reaches maximal effectiveness after exposure of cells to approximately $0.4-0.5$ Gy and then does not increase further (Bakkenist and Kastan 2003).

To conclude, tissue homeostasis depends on balance among cell proliferation, senescence and cell death/apoptosis. Ionizing radiation-induced damage stops cell cycle progression and triggers temporary cell cycle arrest in $\mathrm{G}_{1} / \mathrm{S}$ or $\mathrm{G}_{2} / \mathrm{M}$ phase. During this period of cell cycle arrest the cells repair DNA damage, mainly double-strand breaks of DNA, which are potentially lethal. If the repair is unsuccessful the cells are removed, in the case of haematopoietic cells mostly by apoptosis. However in some cells the cell cycle arrest becomes permanent, these cells lose their proliferative potential; this condition is known as premature senescence. If these control mechanisms fail, the cells with impaired genetic information may persist, this can result in cancerogenesis.

Interestingly, HSC may be protected from small doses irradiation due to their position in the postulated bone marrow niche, which is thought to be hypoxic (Moore and Lemischka 2006). Moreover, the fact that HSC cycle infrequently and have concomitantly low metabolic activity may also serve to limit their exposure oxidative stress (Gazit et al. 2008).

\section{Detection of double strand break (DSB)}

The early molecular mechanisms of response of HSC to radiation-induced DSB are largely unknown. Most of the currently available information was obtained during studies of immortalized cell lines. In response to DSB three proteins from a family of phosphatidylinositol-3-kinase-like proteinkinases are quickly activated: ataxiateleangiectasia mutated (ATM), ataxia-teleangiectasia and Rad3-related (ATR) and catalytic subunit of DNA-dependent proteinkinase (DNA-PKcs). Under normal conditions kinase ATM is present in the cell in the form of inactive, nonphosphorylated dimmer. ATM is quickly - within minutes - activated after irradiation by ionizing radiation, and this activation can be detected in the cells in all cell cycle phases. During activation ATM dimmer dissociates to monomers and is phosphorylated on serine 1981. Dose-dependence studies showed that phosphorylation of serine 1981 was detectable after dose as low as 0.1 Gy, that it was maximal at 0.4 Gy at a $15 \mathrm{~min}$ time point, and that no further increase was seen between 1 and 9 Gy (Bakkenist and Kastan 2003).

Very quickly upon induction of DSB also changes in DSB flanking chromatin occur. Within minutes after irradiation nucleosomal histone H2AX is phosphorylated on serine 139 by ATM kinase. This phosphorylation spreads on DSB flanking chromatin regions, many molecules, often thousands, of $\mathrm{H} 2 \mathrm{AX}$ become rapidly phosphorylated at the site of each nascent DSB. Other proteins are then bound to modified chromatin, e.g. adaptor protein 53BP1 and protein foci are formed around each DSB. These foci are also known as IRIF ionizing radiation-induced foci. Many proteins involved in repair and death processes are recruited into these foci. Among proteins, which co-localize with phosphorylated H2AX (also known as $\gamma \mathrm{H} 2 \mathrm{AX}$ ) and 53BP1 are ATM kinase, Mre11, Rad50, Nbs1 (proteins of DNA-repair complex MRN), Mdc1, and Brca1. Recruitment of these proteins is not dependent on cell cycle phase. Interaction of these proteins in site of DSB is crucial for proper repair (Bekker-Jensen et al. 2006). Significant difference in formation of $\gamma \mathrm{H} 2 \mathrm{AX}$ foci after irradiation of cells from mice or humans that were normal $\left(\mathrm{Atm}^{+/+}\right)$, heterozygous $\left(\mathrm{Atm}^{+-}\right)$, or homozygous recessive $\left(\mathrm{Atm}^{-/}\right)$was found by Kato et al. (2006ab). After $24 \mathrm{~h}$ exposure of mice of low-dose-rate irradiation at $10 \mathrm{cGy} / \mathrm{h}$, appreciable differences in the levels of gamma-H2AX foci per cell were observed in cells from $\mathrm{ATM}^{+/+}$cells (1.77), $\mathrm{ATM}^{+/-}$cells (4.75) and $\mathrm{ATM}^{-/-}$cells (11.10) (Kato et al. 2006b).

Although IRIF formation was not studied so far in HSC, using $\gamma \mathrm{H} 2 \mathrm{AX}$ detection Rossi et al. (2007) compared accumulation of DNA damage in long-term haematopoietic stem cells isolated from bone marrow of old (122 weeks) and young (10 weeks) mice. LT-HSC from young mice did not contain $\gamma \mathrm{H} 2 \mathrm{AX}$ foci, while in $82 \%$ of LT-HSC isolated from old 
mice $\gamma \mathrm{H} 2 \mathrm{AX}$ was detected. More than $70 \%$ of old mice LT-HSC contained more than one $\gamma \mathrm{H} 2 \mathrm{AX}$ focus. This study proves that endogenous DNA damage accumulates with aging in wild type stem cells.

Proteins important in the cell cycle arrest regulations as p53, phosphatase cdc25A, checkpoint kinases 1 and 2 are not accumulated in the site of DSB, but their activation is catalyzed by active ATM released from IRIF. Phosphorylation of p53 e.g. is detected also very soon after DSB induction, but diffusely in the entire nucleus (Bekker-Jensen et al. 2006).

\section{DSB repair}

Two processes prevail in DSB repair: 1) homologous recombination (HR) and 2) nonhomologous end-joining (NHEJ) (Jackson 2002). In eukaryotic cells the major pathway is NHEJ, while more simple prokaryotic organisms (e.g. yeast) rely mostly on HR. For optimalisation of DNA repair the cell must also control other processes related to DNA metabolism, mainly replication of DNA and mitosis. When the damage is induced or detected during replication, it is beneficial to slow the process; therefore cell cycle is arrested in key checkpoints (transitions from $\mathrm{G}_{1}$ to $\mathrm{S}$ and from $\mathrm{G}_{2}$ to $\mathrm{M}$ phase) after DSB induction.

HR occurs in late $S$ phase, mainly in the site of replication fork, and in $G_{2} / M$ phase. During HR sister copy of DNA is required as template for correct rejoining of DNA lesion. Key proteins in HR pathway are Rad52, Rad51 and its homologues, XRCC2, and XRCC3. Rad51 directly interacts with XRCC3. Activity of Rad51 can be directly stimulated by Rad54 and ATP-dependent ATPase, and also modulated by phosphorylation catalyzed by cAbl tyrosinkinase.

On the other hand NHEJ is responsible for repair of DNA DSB during all phases of cell cycle, including $\mathrm{G}_{0}$. In the repair mechanism by NHEJ the most important proteins are DNA-dependent protein kinase with heterodimeric subunit of $\mathrm{Ku} 70$ and $\mathrm{Ku} 80$, DNAligase IV, and XRCC4 (Lieber et al. 2003).

Activated ATM kinase is also involved in regulations of Mre11/Rad50/Nbs1 (MRN) complex functions. MRN complex appears to be the major sensor of the breaks and subsequently recruits ATM, but in turn its components are phosphorylated in processes dependent on ATM. Part of MRN complex, Nbs1 (Nijmegen breakage syndrome protein 1), is important in DNA repair. Its defects result in Nijmegen breakage syndrome, a disease with characteristics similar to ataxia-teleangiectasia - including increased radiosensitivity of cells. Someya et al. (2007) describe relocalisation of Nbs1 into IRIF in peripheral lymhocytes from patients with sporadic breast cancer, where it persisted for $24 \mathrm{~h}$ after irradiation. Patients with impaired DNA repair characterized by low DNA-PK or increased amount of Nbs1 in IRIF $24 \mathrm{~h}$ after irradiation had aggressive tumor phenotypes.

Different mutations in genes which code DNA-repair proteins can cause accelerated aging, premature senescence, and are potentially tumorigenic. DNA-PK is one of key components in NHEJ pathway of repair. Mice deficient in DNA-PK have shorter lifetime, increased occurrence of malignant diseases, and loss of bone density (Espejel et al. 2004). Also mice deficient in ATM develop osteopaenia (Hishiya et al. 2005). In humans, mutations in Atm gene cause the disease ataxia-teleangiectasia, similarly characterized by accelerated aging and increased occurrence of malignancies, mainly in haematopoietic system (Shiloh et al. 1982).

Due to activation of genome integrity guardians, DSB also trigger cell death by apoptosis. As a result of cell removal the number of stem cells decreases and tissue cellularity decreases. Beside apoptosis that leads to cell death, DNA damage can also trigger senescence which can be characterized as ongoing response of the cells to the DNA damage via repair mechanisms, which fails in DNA repair but protect the cells from apoptosis. It seems that persisting foci $(\gamma \mathrm{H} 2 \mathrm{AX})$ can be marker of cells in senescence (Von Zglinicki 2005). 


\section{Protein p53}

Protein p53 is also known as "guardian of the genome", as it is important in many protective pathways, which limit proliferation of damaged, potentially preneoplastic cells. It is involved in induction of both apoptosis and senescence. In normal cells the amount of p53 is low, and the concentration of p53 is controlled by inhibitors Mdm2 (murine double minute 2) and Mdmx (murine double minute $\mathrm{X}$ ). When these inhibitors are missing, p53 is accumulated in nucleus. Mice deficient for Mdm2 die early in development, while mice deficient for both Mdm2 and p53 develop normally and are viable (Jones et al. 1995). Increase in p53 in response to DNA damage is achieved mainly by inhibition of p53 degradation (Chenab et al. 1999).

Mice deficient in p53 develop tumours at early age, and therefore cannot be used for studies of aging (Donehower et al. 1992). Tyner et al. (2002) constructed p53 mutant strain of mice with increased amount of $\mathrm{p} 53$; these mice were labelled as $\mathrm{p} 53^{+/ \mathrm{m}}$. In the studies of spontaneous tumour development these mice only developed tumours in $6 \%$ of individuals, while normal p53 $3^{+/+}$mice in $50 \%$, and p $53^{+/-}$in $100 \%$ of individuals. However, despite the decreased incidence of tumours in $\mathrm{p} 53^{+/ \mathrm{m}}$ strain these mice have $20 \%$ shorter life-time in comparison with $\mathrm{p} 53^{+/+}$mice. P53 $3^{+/ m}$ mice develop normally to 12 months of age, but by the age of 18 months majority of them develop old age diseases (osteoporosis, muscle atrophy, lymphoid atrophy, diminished stress resistance, weight reduction etc.). Early onset of aging-related complications in mice with increased amount of p53 support sthe theory that p53 is responsible for prevention of tumour development, but also leads to the shortening of life-time due to accelerated aging (Donehower 2002).

How does p53 status affect the ability of donor cells to restore recipient's haematopoiesis after lethal irradiation? Hirabayashi et al. (2002) compared transplantation efficiency of bone marrow cells isolated from p53-deficient ( $\left.\mathrm{p} 53^{-/}\right)$, p53-heterozygous ( $553^{+/}$) a wild type $\left(\mathrm{p} 53^{+/+}\right)$mice. They collected repopulated spleens $14^{\text {th }}$ day after transplantation into lethally irradiated mice and $10^{7}$ cells from these repopulated spleens transplanted into secondary lethally irradiated recipient, and repeated the series of transplantations 5 times. Number of $\mathrm{p} 53^{-/-}$and $\mathrm{p} 53^{+/-}$cells increased logarithmically till fourth and fifth passage, while wild type $\mathrm{p} 53^{+/+}$cells ceased proliferation after third passage. Also number of macroscopically visible colonies on spleen increased logarithmically till third passage in the case of $\mathrm{p} 53^{-/-}$and $\mathrm{p} 53^{+/-}$ cells, but decreased as soon as after second passage of wild type p53 $3^{+/+}$cells. From these experiments it can be concluded that p53 deficient bone marrow cells proliferate more quickly then p53 wild type cells.

Loss of p53 has also radioprotective effect. While the p53 wild type mice irradiated by the dose of $10 \mathrm{~Gy}$ all die till $15^{\text {th }}$ day after the irradiation, mice deficient in p53 are more radioresistant and survive (Westphal et al. 1998). On the other hand, when ATM kinase, which activates p53 and cooperates with p53 in apoptosis induction and tumourigenesis suppression, is lost, it has completely different effect: deficiency in ATM is radiosensitising (Westphal et al. 1997).

\section{Stress-induced premature senescence}

Studies on human fibroblasts have shown that uncapped, dysfunctional telomeres and telomeres shortening induce replicative senescence (Wright and Shay 1992). Studies on DNA repair deficient mice and telomerase knockout mice have shown that DNA damage (Nijnik et al. 2007) and telomere dysfunction (Choudhury et al. 2007; Nalapareddy et al. 2008) limit the function of adult stem cells. In contrast to the decline in haematopoietic progenitor cells during human aging, the number of HSCs increases during aging in some of laboratory inbred mouse strains including the C57Bl/6J strain. Studies on telomere dysfunctional and DNA repair deficient mice have shown that progenitor cells appear to be more sensitive to DNA damage than stem cells. One possible explanation for these findings 
is that quiescent stem cells may be better protected against DNA damage compared to transient amplifying cells (Nalapareddy et al. 2008).

In some types of cells, such as fibroblasts, DNA damage (induced for example by ionizing radiation) leads to stress-induced premature senescence. The cells in stressinduced premature senescence have all characteristics of replicative senescence such as $\beta$-galactosidase positivity, p21 accumulation, and hypophosphorylation of $\mathrm{pRb}$. Stressinduced premature senescence is probably induced by p53-dependent cell cycle arrest (Toussaint et al. 2000). The pathway seems to be activated through ATM kinase, phosphorylation of $\mathrm{H} 2 \mathrm{AX}$, formation of $\gamma \mathrm{H} 2 \mathrm{AX}$ foci, and loss of telomeric DNA (Von Zglinicki 2002).

When haematopoietic progenitor cells are damaged by high doses of radiation or chemotherapeutic drugs, HSC react by initiation of self-renewal and proliferation, and its progeny differentiate into particular progenitor cells. Irradiation of mouse bone marrow cells in vitro by the dose of 4 Gy induces apoptosis in both, HSC $\left(\operatorname{lin}-\mathrm{Sca}-1^{+} \mathrm{CD} 117^{+}\right)$and progenitors (lin-Sca- $1^{-} \mathrm{CD} 117^{+}$). In the long-term culture $33 \%$ of these cells survived for 5 weeks after irradiation, but these cells lost their ability to form colonies. These surviving cells had increased amount of $\beta$-galactosidase and p16, which is considered as a mark of senescence (Meng et al. 2003). Irradiation of mouse in vivo has similar results: Mice irradiated by the sublethal dose of 6.5 Gy in vivo have reduced number of HSC, and these HSC bear marks of senescence (increase in $\beta$-galactosidase and p16). Induction of senescence in HSC is related to increase in cell cycle regulatory proteins $\mathrm{p} 21, \mathrm{p} 19$, and p16. However, exposure to ionizing radiation did not trigger increase in senescence markers in haematopoietic progenitors (Wang et al. 2006a).

It seems that activation of p53 and increase in p21 (which is the pathway related with telomere shortening) induces reversible senescence. When the activity of telomerase increases the cells can enter cell cycle again and restore proliferation. On the other hand, following p53 activation also pathways triggering increase in p16 can be activated, and p16 increase induces irreversible senescence. Both pathways are important in induction of senescence, but only p16 is responsible for induction of irreversible senescence (Tous saint et al. 2000).

Molecular mechanisms of stress-induced premature senescence leading to increased p16 are much less elucidated then $\mathrm{p} 53$ pathway. The pathway of p16 activation is triggered by DNA damage or increased expression of oncogenes, consecutively Ras mitogenic pathway is activated and p16 increases. p16 $6^{\mathrm{INK} 4 \mathrm{a}}$ is an inhibitor of cyclin-dependent kinases Cdk4 and Cdk6. Increased amount of p16 causes hypophosphorylation of $\mathrm{pRb}$ and senescence (Dimri 2005).

Generally, the cells with low amount of p16 during aging can restore proliferation after p53 inactivation, while in cells with high amount of p16 the loss of proliferative capacity is irreversible and proliferation cannot be restored by p53 inactivation. Stressinduced premature senescence through p16 upregulation was proved in embryonic diploid fibroblasts WI38 (Probin et al. 2007), but also in murine haematopoietic stem cells (Wang et al. 2006 b). This mechanism seems to be related mainly to DSB of DNA, as busulphan, an alkylating agent, which damages DNA molecules by alkylation and formation of intrastrand crosslinks seems to be p53 independent and depends on activation of MAPK pathways of Erk1/2 and p38 (Probin et al. 2007).

\section{Conclusion}

Fig. 2 summarizes processes, which are activated in the cells after exposure to DNAdamaging genotoxic stressor, such as ionizing radiation. In reaction to DNA damage repair mechanisms are triggered. One of the most important pathways that respond to radiation-induced DSB is phosphorylation of ATM, and phosphorylation and upregulation 


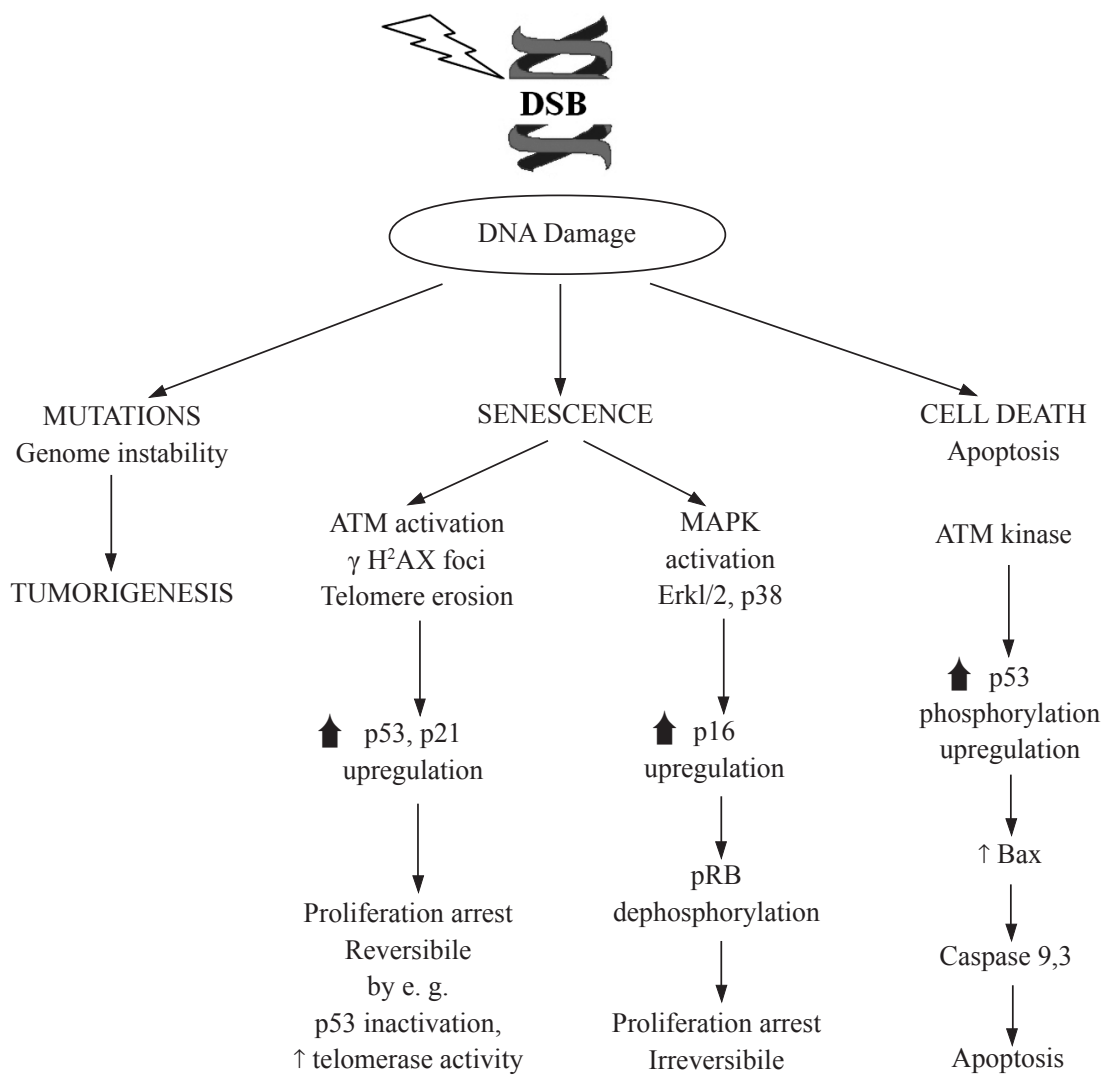

Fig. 2. Reaction of the cell to DNA damage induced by ionizing radiation

of p53. Protein p53 is critically important tumor suppressor protein, which organizes both emergency processes - apoptosis induction and stress-induced premature senescence. The decision which one of them prevails in the reaction to stress is a multifactorial process. It depends on cell type, actual proliferative activity, p53 status, but also on the ability to upregulate $\mathrm{Cdk}$ inhibitor $\mathrm{p} 16$. From the point of view of long-term damage of haematopoiesis after irradiation these processes play very important role. Even when certain percentage of haematopoietic stem cells evade apoptosis induced by high sublethal doses and survive the irradiation, many of them lose the ability to proliferate due to induction of senescence. This loss of proliferative capacity of HSC has critical importance in long-term survival of irradiated organism.

\section{Apoptóza a senescence - hlavní mechanismy urychleného stárnutí hematopoetických buněk po ozáření}

Kmenová buňka krvetvorby patř́ $\mathrm{v}$ organismu mezi buňky nejcitlivější $\mathrm{k}$ účinku ionizujícího záŕení. V tomto přehledu jsou popsány mechanismy, jakými reaguje kmenová buňka krvetvorby se schopností sebeobnovy - HSC (u myší charakterizovaná jako buňka lin-Sca- $1^{+} \mathrm{CD} 117^{+}$) na dvojité zlomy DNA (DSB) vyvolané ionizujícím zářením. V místě DSB dochází ke kolokalizaci 53BP1, $\gamma \mathrm{H} 2 \mathrm{AX}$ a dalších proteinů. Na reparaci poškození se podílí 
mnoho proteinů především kinasy ATM, ATR a DNA-PK, komplex MRN, a proteiny homologní rekombinace a nehomologního spojení konců. V důsledků opakovaného ozáření malými dávkami záření dochází u HSC k akumulaci proteinů do tzv. „,ionizujícím zářením vyvolaných ohnisek" (detekované pomocí $\gamma \mathrm{H} 2 \mathrm{AX}$ ) a také snížení reparační schopnosti HSC. Dále jsou diskutovány především dva možné molekulární mechanismy reakce HSC na poškození zářením - indukce apoptózy a senescence. Zatímco většina diferencovaných hematopoetických buněk, buňky leukemické i hematopoetické progenitory umírají po ozáření apoptózou, u HSC byla prokázána také senescence. Zdá se, že i zmenšení proliferační kapacity HSC spojené se stárnutím je vyvoláno především poškozením DNA kmenové buňky kyslíkovými radikály a akumulací poškození v rezervoáru převážně spících kmenových buněk.

\section{Acknowledgements}

The authors thank the Grant Agency of the Czech Republic (grant project no. 304/08/0329) and the Ministry of Defence of the Czech Republic (projects MO0FVZ0000501) for financial support.

\section{References}

Aldridge DR, Radford IR 1998: Explaining differences in sensitivity to killing by ionizing radiation between human lymphoid cell lines. Cancer Res 58: 2817-2824

Abedi M, Greer DA, Colvin GA, Demers DA, Dooner MS, Harpel JA, Weier HU, Lambert JF, Quesenberry PJ 2004: Robust conversion of marrow cells to skeletal muscle with formation of marrow-derived muscle cell colonies: a multifactorial process. Exp Hematol 32: 426-434

Bakkenist C, Kastan MB 2003: DNA damage activates ATM through intermolecular autophosphorylation and dimmer dissociation. Nature 421: 499-506

Bekker-Jensen S, Lukas C, Kitagawa R, Melander F, Kastan MB, Bartek J, Lukas J 2006: Spatial organization of the mammalian genome surveillance machinery in responce to DNA strand breaks. Cell Biol 173: 195-206

Chenab NH, Malikzay A, Stavridi ES, Halozonetis TD 1999: Phosphorylation of serine 20 mediates stabilization of human p53 in response to DNA damage. Proc Natl Acad Sci USA 96: 13777-13782

Choudhury AR, Ju Z, Djojosubroto MW, Schienke A, Lechel A, Schaetzlein S, Jiang H, Stepczynska A, Wang C, Buer J, Lee HW, Von Zglinicki T, Ganser A, Schirmacher P, Nakauchi H, Rudolph KL 2007: Cdkn1a deletion improves stem cell function and lifespan of mice with dysfunctional telomeres without accelerating cancer formation. Nat Genet 39: 99-105.

Denekamp J 1986: Cell kinetics and radiation biology. Int J Radiat Biol Relat Stud Phys Chem Med 49:357-380

Dimri GP 2005: What has senescence got to do with cancer? Cancer Cell 7: 505-512

Donehower LA 2002: Does p53 affect organismal aging? J Cell Physiol 192: 23-33

Donehower LA, Harvey M, Slagle BL, McArthur MJ, Montgomery CA Jr, Butel JS, Bradley A 1992: Mice deficient for p53 are developmentally normal but susceptible to spontaneous tumours. Nature 356: $215-221$

Espejel S, Martín M, Klatt P, Martín-Caballero J, Flores JM, Blasco MA 2004: Shorter telomeres, accelerated ageing and increased lymphoma in DNA-PKcs-deficient mice. EMBO Rep 5: 503-509

Filip S, English D, Mokrý 2004: Issues in stem cell plasticity. J Cell Mol Med 8: 572-577

Gazit R, Weissman IL, Rossi DJ 2008: Hematopoietic stem cells and the aging hematopoietic system. Semin Hematol 45: 218-224

Hertveld K, Philippé J, Thierens H, Cornelissen M, Vral A, De Ridder L 1997: Flow cytometry as a quantitative and sensitive method to evaluate low dose radiation induced apoptosis in vitro in human peripheral blood lymphocytes. Int J Radiat Biol 71: 429-433

Hirabayashi Y, Matsuda M, Aizawa S, Kodama Y, Kanno J, Inoue T 2002: Serial transplantation of p53-deficient hemopoietic progenitor cells to assess their infinite growth potential. Exp Biol Med (Maywood) 227: 474-479

Hishiya A, Ito M, Aburatani H, Motoyama N, Ikeda K, Watanabe K 2005: Ataxia telangiectasia mutated (Atm) knockout mice as a model of osteopenia due to impaired bone formation. Bone 37: 497-503

Jackson SP 2002: Sensing and repairing DNA double-strand breaks. Carcinogenesis 23: 687-696

Jones SJ, Roe AE, Donehower LA, Bradley A 1995: Rescue of embryonic lethality in MDM2-deficient mice by absence of p53. Nature 378: 206-208

Kato TA, Nagasawa H, Weil MM, Little JB, Bedford JS 2006 a: Levels of gamma-H2AX foci after low-dose-rate irradiation reveal a DNA DSB rejoining defect in cells from human ATM heterozygotes in two at families and in another apparently normal individual. Radiat Res 166:443-453

Kato TA, Nagasawa H, Weil MM, Genik PC, Little JB, Bedford JS 2006 b: gamma-H2AX foci after low-doserate irradiation reveal atm haploinsufficiency in mice. Radiat Res 166: 47-54

Khanna KK, Jackson SP 2001: DNA double-strand breaks: signaling, repair and the cancer connection. Nat Genet 27: 247-254

Kiel MJ, Yilmaz ÖH, Iwashita T, Yilmaz OH, Terhorst C, Morrison SJ 2005: SLAM family receptors distinguish hematopoietic stem and progenitor cells and reveal endothelial niches for stem cells. Cell 121: 1109-1121 
Kozubek S 2000: Účinky záření na subcelulární systémy a na buňku In: Klener V (Ed.): Principy a praxe radiační ochrany. Azin CZ, Praha, pp. 153-168.

Kroger LA, Denardo GL, Gumerlock PH, Xiong CY, Winthrop MD, Shi XB, Mark PC, Leshchinsky T, Denardo SJ 2001: Apoptosis/related gene and protein expression in human lymphoma xenografts /Raji/ after low dose rate radiation using 67Cu-2IT-BAT-Lym-1. Cancer Biother Radiopharm 16: 213-225

Laver J, Kwon JH, Castro-Malaspina H 1987: Effects of low dose rate irradiation on human marrow hematopoietic and microenvironmental cells: sparing effect upon survival of stromal and leukemic cells. Bone Marrow Transplant 2: 271-278

Lieber MR, Ma Y, Pannicke U, Schwarz K 2003: Mechanism and regulation of human non-homogenous DNA end-joining. Nat Rev Mol Cell Biol 4: 712-720

Louagie H, Cornelissen M, Philippé J, Vral V, Thierens H, De Ridder L 1998: Flow cytometric scoring of apoptosis compared to electron microscopy in gamma irradiated lymphocytes. Cell Biol Int 22: 277-283

Meng A, Wang, Y, Zant GV, Zhou D 2003: Ionizing radiation and busulfan induce premature senescence in murine bone marrow hematopoietic cells. Cancer Res 63: 5414-5419

McCulloch EA, Till JE 1962: The sensitivity of cells from normal mouse bone marrow to gamma radiation in vitro and in vivo. Radiat Res 16: $822-832$

Moore KA, Lemischka IR 2006: Stem cells and their niches. Science 311: 1880-1885

Morrison SJ, Uchida N, Weissman IL 1995: The biology of hematopoietic stem cells. Annu Rev Cell Dev Biol 11: $35-71$

Nalapareddy K, Jiang H, Guachalla Gutierrez LM, Rudolph KL 2008: Determining the influence of telomere dysfunction and DNA damage on stem and progenitor cell aging - what markers can we use? Exp Gerontol 43: $998-1004$

Nijnik A, Woodbine L, Marchetti C, Dawson S, Lambe T, Liu C, Rodrigues NP, Crockford TL, Cabuy E, Vindigni A, Enver T, Bell JI, Slijepcevic P, Goodnow CC, Jeggo PA, Cornall RJ 2007: DNA repair is limiting for haematopoietic stem cells during ageing. Nature 447: 686-90

Ning S, Knox SJ 1999: G/M-phase arrest and death by apoptosis of HL-60 cells irradiated with exponentially decreasing low-dose-rate gamma radiation. Radiat Res 151: 659-669

Probin V, Wang Y, Zhou D 2007: Busulfan-induced senescence is dependent on ROS production upstream of the MAPK pathway. Free Radic Biol Med 42: 1858-1865

Randall TD, Lund FE, Howard MC, Weissman IL 1996: Expression of murine CD38 defines a population of longterm reconstituting hematopoietic stem cells. Blood 87: 4057-4067

Rossi DJ, Bryder D, Zahn JM, Ahlenius H, Sonu R, Wagers AJ, Weissman IL 2005: Cell intrinsic alterations underlie hematopoietic stem cell aging. Proc Natl Acad Sci USA 102: 9194-9199

Rossi DJ, Bryder D, Seita J, Nussenzweig A, Hoeijmakers J, Weissman IL 2007: Deficiencies in DNA damage repair limit the function of haematopoietic stem cells with age. Nature 447: 725-729

Shiloh Y, Tabor E, Becker Y 1982: Colony-forming ability of ataxia-telangiectasia skin fibroblasts is an indicator of their early senescence and increased demand for growth factors. Exp Cell Res 140: 191-199

Shore RE 1999: Assessing risk at low doses. In: Baumstark-Khan C, Kozubek S, Horneck G (Eds.): Fundamentals for the assessment of risks from environmental radiation. Kluger Academic Publisher, pp. 7-14.

Someya M, Sakata K, Matsumoto Y, Tauchi H, Narimatsu H, Hareyama M 2007: Association of DNA-PK activity and radiation-induced NBS1 foci formation in lymphocytes with clinical malignancy in breast cancer patients. Oncol Rep 18: 873-878

Szkanderová S, Vávrová J, Řezáčová M, Vokurková D, Pavlová Š, Šmardová J, Stulík J 2003: Gamma irradiation results in phosphorylation of p53 at serine-392 in human T-lymphocyte leukaemia cell line MOLT-4. Folia Biol (Praha) 49: 191-196

Till JE, McCulloch EA 1961: A direct measurement of the radiation sensitivity of normal mouse bone marrow cells. Radiat Res 14: 213-222

Toussaint O, Medrano EE, Von Zglinicki T 2000: Cellular and molecular mechanisms of stress- induced premature senescence (SIPS) of human diploid fibroblasts and melanocytes. Exp Gerontol 35: 927-945

Tyner SD, Venkatachalam S, Choi J, Jones S, Ghebranious N, Igelmann H, Lu X, Soron G, Cooper B, Brayton C, Hee Park S, Thompson T 2002: p53 mutant mice that display early ageing-associated phenotypes. Nature 415: $45-53$

Vávrová J, Petýrek P 1986: Late effects of single and repeated sublethal gamma radiations on haemopoietic stem cells in mice. Folia Biol (Praha) 32: 399-405

Vávrová J, Petýrek P 1988: Effect of short-term splitting of gamma-ray doses on changes in haemopoietic stem cell number in bone marrow and on mortality of whole-body irradiated mice. Folia Biol (Praha) 34: 399-408

Vávrová J, Mareková M, Vokurková D 2001: Radiation-induced apoptosis and cell cycle progression in TP53deficient human leukemia cell line HL-60. Neoplasma 48: 26-33

Vávrová J, Vokurková D, Mareková M, Bláha M, Jebavý L, Filip S 2002: Antiapoptotic cytokine IL-3 + SCF + FLT3L influence on proliferation of gamma-irradiated AC133+/CD34+ progenitor cells. Folia Biol (Praha) 48: $51-57$

Vávrová J, Mareková M, Vokurková D, Szkanderová S, Psutka J 2003: Caffeine induces a second wave of apoptosis after low dose-rate gamma radiation of HL-60 cells. Radiat Environ Biophys 142: 193-199 
Vávrová J, Řezáčová M, Vokurková D, Psutka J 2004: Cell cycle alteration and response to low-dose-rate gamma radiation in leukemic cell lines. Physiol Res 53: 335-342

Vilasová Z, Řezáčová M, Vávrová J, Tichý A, Vokurková D, Zoelzer F, Řeháková Z, Osterreicher J, Lukášová E 2008: Changes in phosphorylation of histone H2A.X and p53 in response of peripheral blood lymphocytes to gamma irradiation. Acta Biochim Pol 55: 381-390

Vokurková D, Sinkora J, Vávrová J, Rezáčová M, Knízek J, Ostereicher J 2006: CD8+ natural killer cells have a potential of a sensitive and reliable biodosimetric marker in vitro. Physiol Res 55: 689-698

Wagers AJ, Sherwood RI, Christensen JL, Weissman IL 2002: Little evidence for developmental plasticity of adult hematopoietic stem cells. Science 297: 2256-22599

Wang Y, Schulte BA, Zhou D 2006 a: Hematopoietic stem cell senescence and long-term bone marrow injury. Cell Cycle 5: 35-38

Wang Y, Schulte BA, Larue A, Ogawa M, Zhou D 2006 b: Total body irradiation selectively induces murine hematopoietic stem cell senescence. Blood 107: 358-366

Weksberg DC, Chambers SM, Boles NC, Goodell MA 2008: CD150- side population cells represent a functionally distinct population of long-term hematopoietic stem cells. Blood 111: 2444-2451

Westphal CH, Rowan S, Schmaltz C, Elson A, Fisher DE, Leder P 1997: ATM and p53 cooperate in apoptosis and suppression of tumorigenesis, but not in resistance to acute radiation toxicity. Nat Genet 16: 397-401

Westphal CH, Hoyes KP, Canman CE, Huang X, Kastan MB, Hendry JH, Leder P 1998: Loss of ATM radiosensitizes multiple p53 null tissues. Cancer Res 58: 5637-5639

Wright WE, Shay JW 1992: The two-stage mechanism controlling cellular senescence and immortalization. Exp Gerontol 27: 383-389

Yang L, Bryder D, Adolfsson J, Nygren J, Månsson R, Sigvardsson M, Jacobsen SE 2005: Identification of Lin(-) Sca1(+)kit(+)CD34(+)Flt3- short-term hematopoietic stem cells capable of rapidly reconstituting and rescuing myeloablated transplant recipients. Blood 105: 2717-2723

Yilmaz OH, Kiel MJ, Morrison SJ 2006: SLAM family markers are conserved among hematopoietic stem cells from old and reconstituted mice and markedly increase their purity. Blood 107: 924-930

Yoshimoto M, Chang H, Shiota M, Kobayashi H, Umeda K, Kawakami A, Heike T, Nakahata T 2005: Two different roles of purified CD45+c-Kit+Sca-1+Lin- cells after transplantation in muscles. Stem Cells 23: 610-618

Von Zglinicki T, Saretzki G, Ladhoff J, D’Adda di Fagagna F, Jackson SP 2005: Human cell senescence as a DNA damage response. Mech Ageing Dev 126: 111-117

Von Zglinicki T 2002: Oxidative stress shortens telomeres. Trends Biochem Sci 27: 339-344

Zhao Y, Lin Y, Zhan Y, Yang G, Louie J, Harrison DE, Anderson WF 2000: Murine hematopoietic stem cell characterization and its regulation in BM transplantation. Blood 96: 3016-3022 